\title{
Cord blood IgE and month of birth
}

\author{
J KIMPEN, H CALLAERT, P EMBRECHTS, AND E BOSMANS
}

Department of Microbiology, Willems-Instituut, and Statistical Research Unit, Limburgs Universitaire Centrum, Diepenbeek, Belgium

SUMMARY If cord blood IgE is used to detect those predisposed to become allergic it is important to define appropriately the normal values for this measurement. A commonly cited cut off point is $1.0 \mathrm{IU} / \mathrm{ml}$. We analysed 5353 cord blood samples for IgE by means of an enzyme linked immunosorbent assay. Descriptive statistics of the distribution curve of cord blood $\operatorname{IgE}$ concentrations showed that most normal values were well below the cut off value of $1.0 \mathrm{IU} / \mathrm{ml}$ and that most abnormal values were in the neighbourhood of $1.0 \mathrm{IU} / \mathrm{ml}$. It seems advantageous, therefore, to lower the cut off value for cord blood IgE.

When cord blood IgE was analysed according to the child's month of birth a significantly uneven distribution of abnormal cases of cord blood IgE concentrations over the year was found. The occurrence of an abnormal cord blood IgE concentration showed a significant cyclic trend, with a peak near the end of April and a trough in late October.

Allergy is a leading cause of morbidity in modern society. (Foucard T. The epidemiology of allergic disease in childhood. Presented at annual meeting of the European Academy of Allergology and Clinical Immunology, Stockholm, 1985.) Prediction of the disease is important because early avoidance of exposure to allergens can postpone or prevent clinical manifestations. Prolonged breast feeding, avoidance of allergens by the pregnant woman and the nursing mother, and gradual and delayed weaning to solid foods may be beneficial in this regard, at least temporarily. ${ }^{1-7}$ This seems to be especially the case in at risk newborns-for example, those with low T cell counts, ${ }^{7}$ a cord blood IgE concentration $>1.0 \mathrm{IU} / \mathrm{ml},{ }^{8}$ or a positive family history for allergy. ${ }^{6} \mathrm{~A}$ prevention programme has to be started as early as possible. A family history of atopy and a high total cord blood IgE concentration are the best predictors of an allergic constitution. ${ }^{18-11}$

Neonatal screening of cord blood IgE concentrations seems warranted for all babies, or at least for the babies at risk because of a positive family history. ${ }^{8-10}$ A cut off value of $1.0 \mathrm{IU} / \mathrm{ml}$ has been used in many studies, but lower values have been proposed. ${ }^{381011}$ In this study we evaluated statistically the distribution of cord blood IgE concentrations in the range below the cut off point of 1.0 $\mathrm{IU} / \mathrm{ml}$.

In addition, we report on the influence of month of birth on cord blood IgE concentrations. Fluctua- tions of the cord blood IgE concentration according to month of birth may have important implications in prevention programmes. A recent publication of Croner and Kjellman emphasised the importance of month of birth in the development of allergy. ${ }^{12}$ The authors concluded that children with a high cord blood IgE concentration who were born in May had the highest risk of developing an allergic disease.

\section{Patients and methods}

Patients. Cord blood samples of 5838 newborns were examined during one year (1985). The children were born in the community hospitals of Genk, Bree, Waterschei, Heusden, Tongeren, Bilzen, Hasselt, and Neerpelt. These hospitals were responsible for $66 \%$ of the deliveries in 1985 in Limburg, a province in the north eastern part of Belgium. The province had 730000 inhabitants and a birth rate of 11.6 per 1000 in 1985 .

Data recorded for each delivery included name of mother and child, sex, month of birth, birth weight (to the nearest $10 \mathrm{~g}$ ), and gestational age (presented as weeks completed from the last menstrual period). All patients with incomplete data, as well as all twins, were excluded from statistical analysis. Thus 326 patients were removed from the study. A high IgA concentration in the cord blood is an indicator for possible contamination with maternal blood, and thus a further 157 cord blood samples were excluded 
from further analysis. A further two patients were excluded as not enough cord blood was available for analysis.

Thus 5353 cord blood samples were finally included in the study, 2723 of them from boys. A total of 3975 of the children (74\%) had two Belgian parents, $820(15 \%)$ had two immigrant parents (mostly from south Europe and north Africa), and $558(10 \%)$ had parents of mixed origin. Cord blood IgE concentrations did not differ significantly between these groups.

Methods. Cord blood serum was examined for IgE and IgA (among other variables) by means of a conventional microtitre sandwich enzyme linked immunosorbent assay (ELISA), as previously described. ${ }^{13}$ The technique for IgE determination has a high reproducibility, is sensitive (detection limit of $0.01 \mathrm{IU} / \mathrm{ml}$ ), and shows an excellent correlation with the conventional paper radioimmunoabsorbent test ${ }^{14}$ and radioimmunoassay ${ }^{15}$ for the concentration range where these techniques can be applied. Antibodies used on the solid phase were goat antihuman IgE (Tago) and rabbit antihuman IgA (Dako), respectively. Antihuman IgE monoclonal antibody (Hybritech) and rabbit antihuman IgA (Dako), conjugated with horseradish peroxidase, were used as second antibody, respectively.

The samples were read on a multichannel spectrophotometer at $450 \mathrm{~nm}$ (Titertek Multiskan MC, Flow Laboratories), connected to a Commodore 8032-SK microprocessor.

The cut off point used for IgE was $1.0 \mathrm{IU} / \mathrm{ml}$ and for IgA was $32.3 \mu \mathrm{g} / \mathrm{ml}$. The latter was calculated as the mean $+3 \mathrm{SD}$, as determined previously in a pilot study of newborns. (Bosmans E. Unpublished data.)

\section{Statistical methods}

Computation of the statistical analyses performed in this paper used the packages MINITAB (Pennsylvania State University) and BMDP-PC (Statistical Software Inc, University of California). Wherever appropriate, we used general descriptive statistical methods, correlation analysis, and the Edwards' test for cyclic trend. ${ }^{16}$ As an alternative to the Edwards' test we could have used the method of Mardia, ${ }^{17}$ but both tests, however, lead to the same conclusion.

As a result of the very skewed shape of the IgE histogram (Figures 1 and 2) we used the KruskalWallis one way analysis of variance (ANOVA) test for the comparison of the sum of group ranks. ${ }^{18}$

\section{Results}

The total cord blood IgE concentration was deter- mined in 5353 cord blood samples. Of these, 182 (3\%) had an IgE concentration above $1.0 \mathrm{IU} / \mathrm{ml}$. Figure 1 shows that most of the abnormal values are close to the cut off point. Of these 182 samples, 119 $(65 \%)$ were lower than $2 \mathrm{IU} / \mathrm{ml}$ and $161(88 \%)$ lower than $4 \mathrm{IU} / \mathrm{ml}$. Higher cord blood concentrations were rare. Figure 2 shows the distribution of the IgE concentrations below or equal to $1.0 \mathrm{IU} / \mathrm{ml}$. Of the 5171 samples with IgE concentrations $\leqslant 1 \cdot 0$ IU $/ \mathrm{ml}, 3747(72 \%)$ had a concentration below $0 \cdot 2$ $\mathrm{IU} / \mathrm{ml}$ and $4659(90 \%)$ below $0.4 \mathrm{IU} / \mathrm{ml}$. Only 512 $(10 \%)$ serum samples with a normal cord blood IgE concentration had a value between 0.4 and 1.0 $\mathrm{IU} / \mathrm{ml}$, with clustering of the $\mathrm{IgE}$ concentrations towards the lower limit of this interval. As a result of the odd distribution pattern near the detection limit we did not attempt to fit a curve to the IgE histogram, although a log normal or gamma distribution seemed appropriate for the normal values.

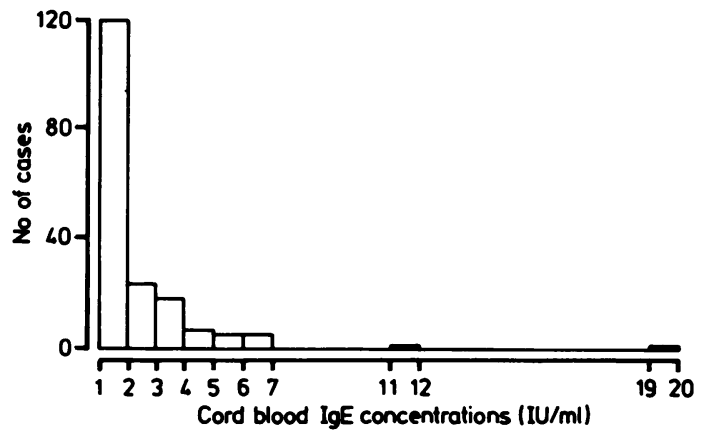

Fig. 1 Histogram of the cases with abnormal cord blood IgE concentrations $(>1.0 I U / \mathrm{mt})(n=182)$. The intervals are (left) open (right) closed. Each interval has a width of $1 \cdot 0 \mathrm{IU} / \mathrm{ml}$.

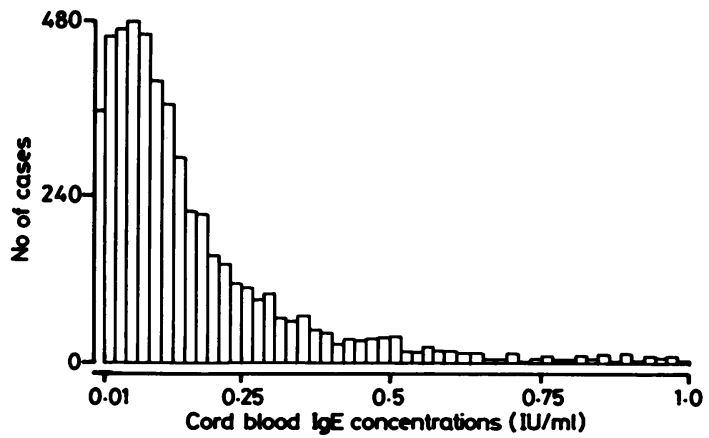

Fig. 2 Histogram of the cases with normal cord blood IgE concentrations $(\leqslant 1.0 \mathrm{IU} / \mathrm{ml})(n=5171)$. The intervals are (left) open (right) closed. Each interval has a width of $0.02 \mathrm{IU} / \mathrm{ml}$, except the first and the last one $(0.01 \mathrm{IU} / \mathrm{ml})$. 
The mean cord blood IgE concentration for the whole population was $0.25 \mathrm{IU} / \mathrm{ml}$, and the median was $0 \cdot 12 \mathrm{IU} / \mathrm{ml}$.

The cord blood IgE concentrations were then analysed according to month of birth. The number of abnormal values was unevenly distributed over

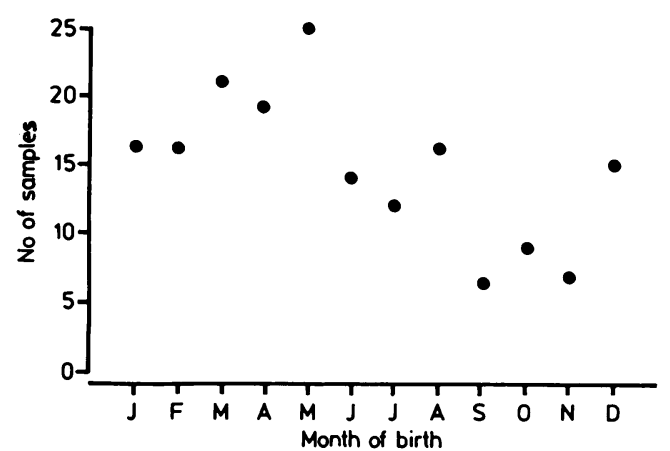

Fig. 3 Adjusted number of samples with a cord blood IgE concentration $>1.0 \mathrm{IU} / \mathrm{ml}$, according to the month of birth. A sinusoidal curve can be fitted through these points and the difference is significant (Edwards' test $=18 \cdot 2$, $d f=2, p<0 \cdot 001$ ).

Table 1 Edwards' test values and significances for different cut off points of cord blood IgE concentrations

\begin{tabular}{llll}
\hline $\begin{array}{l}\text { Cut off } \\
\text { points } \\
(I U / m l)\end{array}$ & $\begin{array}{l}\text { Edwards' } \\
\text { test }\end{array}$ & $\begin{array}{l}\text { Degree of } \\
\text { freedom }\end{array}$ & p Value \\
\hline 1.0 & 18.2 & 2 & $<0.001$ \\
0.9 & 21.2 & 2 & $<0.001$ \\
0.8 & 27.9 & 2 & $<0.001$ \\
0.7 & 29.6 & 2 & $<0.001$ \\
\hline
\end{tabular}

the year. Figure 3 shows a plot of the number of samples with a IgE concentration above $1.0 \mathrm{IU} / \mathrm{ml}$ (the numbers were adjusted for the overall distribution of births over the whole year). A clear cyclic pattern emerged. A simple sinusoidal function was fitted using the Edwards' test $(p<0 \cdot 001) .{ }^{16}$ The resulting fit showed a maximum around late April and a minimum around late October. When the cut off point was lowered to $0 \cdot 9,0 \cdot 8$, or $0.7 \mathrm{IU} / \mathrm{ml}$ the same pattern emerged (Table 1). The number of normal cases (cord blood $\mathrm{IgE} \leqslant 1.0 \mathrm{IU} / \mathrm{ml}$ ) did not show any particular pattern as a function of the month of birth (data not shown).

Next, the absolute values of cord blood IgE were analysed according to month of birth for two groups. Firstly, all samples were analysed together (group A). Then the group with a normal cord blood $\operatorname{IgE}$ concentration was analysed separately (group B). The group of abnormal cases (cord blood $\operatorname{IgE}>1 \cdot 0$ $\mathrm{IU} / \mathrm{ml}$ ) showed no significant difference in mean or median IgE concentrations between different months. The size of this group was too small, however, to pursue this point any further. For group A the difference in absolute cord blood IgE concentrations over the months was highly significant (Kruskal-Wallis, ANOVA test, $\mathrm{p}<0.0001$ ). The months with the greatest number of abnormal cord blood IgE concentrations (March, April, and May) also had the highest mean IgE concentrations. May was the most remarkable month, with a mean cord blood $\mathrm{IgE}$ concentration of $0.34 \mathrm{IU} / \mathrm{ml}$ and a median of $0.15 \mathrm{IU} / \mathrm{ml}$ (Table 2). The same trend was found when the normal IgE values were analysed separately (group B) (Kruskal-Wallis value $=68 \cdot 65$, $\mathrm{df}=11, \mathrm{p}<0.0001)($ data not shown $)$.

Table 2 No of births with normal and abnormal cord blood $\operatorname{IgE}$ concentrations and mean and median cord blood IgE concentrations according to month of birth

\begin{tabular}{|c|c|c|c|c|c|}
\hline \multirow[t]{2}{*}{ Month of birth } & \multirow{2}{*}{$\begin{array}{l}\% \text { (Cumulative } \%) \\
\text { Of total No } \\
\text { of births }(n=5353)\end{array}$} & \multicolumn{2}{|c|}{$\begin{array}{l}\text { No (adjusted) with } \\
\text { observed cord blood IgE }\end{array}$} & \multicolumn{2}{|c|}{$\begin{array}{l}\text { Absolute cord blood } \\
(I U / \mathrm{ml})\end{array}$} \\
\hline & & Normal & Abnormal & Mean & Median \\
\hline January & $6 \cdot 2 \quad(6 \cdot 2)$ & $319(429)$ & $12(16)$ & 0.22 & 0.11 \\
\hline February & $7 \cdot 8 \quad(14 \cdot 0)$ & 401 (428) & $15(16)$ & 0.25 & 0.12 \\
\hline March & $9.8 \quad(23.8)$ & $503(428)$ & $25(21)$ & 0.29 & 0.12 \\
\hline April & $9.4 \quad(33 \cdot 2)$ & $481(426)$ & $22(20)$ & 0.27 & 0.13 \\
\hline May & $9 \cdot 3 \quad(42 \cdot 5)$ & $468(419)$ & $28(25)$ & 0.34 & 0.15 \\
\hline July & $9.6 \quad(60.7)$ & 504 (437) & $14(12)$ & 0.26 & 0.12 \\
\hline August & $7.7 \quad(68.4)$ & $396(429)$ & $15(16)$ & 0.24 & 0.11 \\
\hline September & $8.6 \quad(77 \cdot 0)$ & $449(435)$ & 7 (7) & 0.19 & $0 \cdot 10$ \\
\hline October & $8 \cdot 3 \quad(85 \cdot 3)$ & $437(439)$ & $9 \quad(9)$ & 0.20 & 0.11 \\
\hline November & $7 \cdot 0 \quad(92 \cdot 3)$ & $368(438)$ & $6 \quad(7)$ & 0.22 & (). 12 \\
\hline December & $7.7(100 \cdot 0)$ & $398(431)$ & $14(15)$ & 0.25 & 0.13 \\
\hline Total & & 5171 & $182^{*}$ & $(1) .25^{* *}$ & $0.12 * *$ \\
\hline
\end{tabular}

${ }^{*}$ Edwards' test value $=18 \cdot 2, \mathrm{df}=2, \mathrm{p}<0 \cdot 001$

${ }^{* *}$ Absolute cord blood mean and median; Kruskal-Wallis value $=76 \cdot 14 . \mathrm{df}=11, \mathrm{p}<(0 \cdot 0(0) 1$. 


\section{Discussion}

Cord blood IgE, which seems to be the single best predictor of allergy, ${ }^{10}{ }^{19}$ was greater than the cut off value of $1.0 \mathrm{IU} / \mathrm{ml}$ in $3 \%$ of newborn babies in this study. This percentage is lower than reported elsewhere. ${ }^{89}$ The mean cord blood IgE concentration was $0.25 \mathrm{IU} / \mathrm{ml}$. Infants with cord blood IgE concentrations below $1.0 \mathrm{IU} / \mathrm{ml}$ had mostly very low concentrations; $90 \%$ of all normal values fell below $0.4 \mathrm{IU} / \mathrm{ml}$. Only a tenth of the samples fell between 0.4 and $1.0 \mathrm{IU} / \mathrm{ml}$. The sensitivity of the screening method might be increased, with little effect on the selectivity, by lowering the cut off limit to 0.9 or even $0.7 \mathrm{IU} / \mathrm{ml}$ if it is assumed that nearly $15 \%$ of children develop atopic disease during childhood and adolescence. ${ }^{6}$ A lower cut off may therefore identify a greater percentage of the at risk population. Most of the abnormal cord blood IgE concentrations are clustered near the cut off point of 1.0 $\mathrm{IU} / \mathrm{ml}$, with only a few high values. Sixty five per cent of the abnormal cord blood IgE values were situated between 1 and $2 \mathrm{IU} / \mathrm{ml}$. These observations are an important argument for the cut off point for normal cord blood IgE values to be lowered. Prospective clinical follow up studies have already substantiated this point of view. ${ }^{3910}$

To detect seasonal influences, cord blood IgE concentrations were analysed according to month of birth. We found a cyclic distribution of the number of abnormal cord blood IgE values over the year. The peak of the sinusoidal curve was situated in the spring (March, April, and May), while the trough was in late October. Not only did we find that more newborns had an abnormal cord blood IgE concentration in spring, but we also found higher overall absolute cord blood IgE concentrations in this season. The non-homogeneity of proportions of abnormal cord blood IgE values over the year does not explain this difference of absolute values according to the month of birth. The difference remained significant when the abnormal values were omitted (group B). Thus it seems that to be born in a particular season carries a high relative risk for an abnormal cord blood IgE concentration and hence a higher risk for the development of an allergic disease.

Until recently, most of the studies published about hypersensitivity in correlation with month of birth used selected patient populations who either already had an allergic disease $\mathrm{e}^{20-22}$ or were predisposed to becoming diseased because of a positive family history. ${ }^{23}$ The study of Croner and Kjellman addressed the importance of month of birth together with a high cord blood IgE concentration in relation to the development of allergy. ${ }^{12}$ Both indices seemed to influence the incidence of atopic disease. But cord blood IgE as such was not evaluated as a function of the month of birth. From our study it seems that month of birth influences the IgE concentration in the cord blood, so that we find a cyclic sinusoidal pattern with higher cord blood IgE values in the spring together with a greater percentage of abnormal values. The reason for this is as yet unclear. Many factors may be involved. The immune regulation of $\mathrm{IgE}$ production is only partly understood. It was not the aim of this study to explore the mechanism behind these significant differences, and further study is certainly needed. Intrauterine sensitisation can probably trigger an IgE mediated response in the newborn. ${ }^{4}$ Highly sensitive antigen specific IgE determination in cord blood (against pollen antigens and others) may become a tool in future research.

From this study we conclude that there is a difference in cord blood IgE concentration in relation to month of birth. This is true both for abnormal values, which show a cyclic sinusoidal pattern over the year, with a peak near the end of April and a trough in late October, and also for the absolute concentration of cord blood IgE, which is higher in the spring and lower in the autumn.

The authors are indebted to Mrs J Bleus, Mrs M Pauly, and Mrs M Boussé, who performed the laboratory analyses, and to all the gynaecologists and midwives of the community hospitals, who provided us with the cord blood samples.

\section{References}

${ }^{1}$ Kjellman NIM. Prediction and prevention of atopic allergy. Allergy 1982;37:463-73.

${ }^{2}$ Leclercq-Foucart J. Prédiction et prévention de l'allergie chez le nourrisson et l'enfant. Rev Méd Liége 1983;38:381-94.

${ }^{3}$ Chandra RK, Puri S, Cheema PS. Predictive value of cord blood $\mathrm{IgE}$ in the development of atopic disease and role of breastfeeding in its prevention. Clin Allergy 1985;15:517-22.

4 Businco L, Cantani A. Prevention of atopy-current concepts and personal experience. Clin Rev Allergy 1984;2:107-23.

5 Saarinen UM, Backman A, Kajosaari M, Siimes MA. Prolonged breast-feeding as prophylaxis for atopic disease. Lancet 1979;ii:163-6.

${ }^{6}$ Businco L, Marchetti F, Pellegrini G, Cantani A, Perlini R. Prevention of atopic disease in "at-risk newborns" by prolonged breast-feeding. Ann Allergy 1983;51:296-9.

${ }^{7}$ Björkstén B. Does breast-feeding prevent the development of allergy? Immunology Today 1983;4:215-7.

8 Duchateau J, Casimir G. Neonatal serum IgE concentration as predictor of atopy. Lancet 1983;i:413-4.

9 Croner S, Kjellman NIM, Eriksson B, Roth A. IgE screening in 1701 newborn infants and the development of atopic disease during infancy. Arch Dis Child 1982;57:364-8.

${ }^{10}$ Kjellman NIM, Croner S. Cord blood IgE determination for allergy prediction. A follow-up to seven years of age in 1651 children. Ann Allergy 1984;53:167-71.

11 Businco L, Marchetti F, Pellegrini G, Perlini R. Predictive value of cord blood IgE levels in "at-risk" newborn babies and influence of type of feeding. Clin Allergy 1983;13:503-8. 
12 Croner S, Kjellman NIM. Predictors of atopic disease: cord blood IgE and month of birth. Allergy 1986;41:68-70.

13 Engvall E, Perlmann P. Enzyme-linked immunosorbent assay (ELISA). Quantitative assay of immunoglobulin G. Immunochemistry 1971;8:871-4.

14 Bayne NK, Mathews KP. Determination of total IgE by ELISA in tubes and plates compared with PRIST. Clin Biochem 1982;15:167-9.

15 Hoffman DR. Estimation of serum IgE by an enzyme-linked immunosorbent assay (ELISA). J Allergy Clin Immunol 1973:51:303-7.

16 Edwards JH. The recognition and estimation of cyclic trends. Ann Hum Genet 1961;25:83-7.

17 Mardia KV. Statistics of directional data. New York: Academic Press, 1972:11, 25, 26, 135.

is BMDP Statistical Software. California: University of California Press, 1981.

19 Michel FB, Bousquet J, Greillier P, Robinet-Levy M,
Coulomb Y. Comparison of cord blood immunoglobulin $E$ concentrations and maternal allergy for the prediction of atopic disease in infancy. J Allergy Clin Immunol 1980;65:422-30.

20 David TJ, Beards SC. Asthma and the month of birth. Clin Allergy 1985;15:391-5.

21 Morrison Smith J, Springett VH. Atopic disease and month of birth. Clin Allergy 1979;9:153-7.

22 Björkstén F, Suoniemi I. Dependence of immediate hypersensitivity on the month of birth. Clin Allergy 1976;6:165-71.

${ }^{23}$ Soothill JF, Stokes CR, Turner MW, Norman AP, Taylor B. Predisposing factors and the development of reaginic allergy in infancy. Clin Allergy 1976:6:305-19.

Correspondence to Dr J Kimpen, Department of Paediatrics, K U Leuven Medical School, U Z Gasthuisberg, Herestraat 49, B-3000 Leuven, Belgium.

Received 4 November 1986 